\title{
WHEATGRASS (TRITICUM AESTIVUM LINN.): A POTENTIAL SUBSTITUTE OF HUMAN BLOOD IN TRADITIONAL SYSTEM OF MEDICINE
}

\author{
SHAILJA CHOUDHARY, HEMLATA KAURAV, GITIKA CHAUDHARY*
}

Shuddhi Ayurveda, Jeena Sikho Lifecare Pvt. Ltd., Zirakpur, Punjab, India. Email: shuddhi.research@jeenasikho.co.in

Received: 23 March 2021, Revised and Accepted: 05 May 2021

\begin{abstract}
Wheatgrass (Triticum aestivum Linn.) refers to the young grass of the common wheat plant which belongs to the family Poaceae. It is known as the powerhouse of nutrients and vitamins. The juice of wheatgrass is known as "green blood" which contains an excessive amount of chlorophyll content (70\% of the total chemical constituents), antioxidants, active enzymes, vitamins, and other vital nutrients which are used to enhance lungs and heart function. Wheatgrass juice is also taken as a supplementary diet to boost the immune system and provide strength to the human body. From reported studies, it is proved that molecules of human blood hemoglobin and wheatgrass chlorophyll contain the same structure and can act as a substitute for hemoglobin in hemoglobin deficiency conditions. It is a highly nutritive plant and is used to cure diseases such as cancer, diabetes, ulcer, rheumatoid arthritis, hyperlipidemia, thalassemia, anemia, kidney stone, asthma, digestive problems, and skin diseases. Pharmacologically, wheatgrass carries properties such as anti-diabetic, anti-allergic, antioxidant, anti-ulcer, anticancer, hepatoprotective, cardioprotective, anti-inflammatory, and antiarthritic properties. In this review paper, attempts have been made to provide a brief overview of wheatgrass, its pharmacological activities, and ayurvedic view.
\end{abstract}

Keywords: Anti-thalassemia, Ayurveda, Green blood, Pharmacological activity, Wheatgrass.

(C) 2021 The Authors. Published by Innovare Academic Sciences Pvt Ltd. This is an open access article under the CC BY license (http://creativecommons.org/ licenses/by/4.0/) DOI: http://dx.doi.org/10.22159/ajpcr.2021v14i6.41575. Journal homepage: https://innovareacademics.in/journals/index.php/ajpcr

\section{INTRODUCTION}

Herbal medicines are considered as the major healthcare provider in the whole world mainly in rural and remote areas. Herbal plants are utilized for medicinal purposes thousands of years back to treat various diseases and disorders [1] (Fig. 1).

Wheatgrass is commonly known as "living food" because of the presence of the highest chlorophyll content which contributes $70 \%$ of the total chemical constituents [2]. Wheatgrass is also considered as nutraceutical as it prevents chronic diseases, improves health, delays the aging process, and increases life expectancy. Dr. Charles is known as the father of wheatgrass. He documented the use of the wheat plant in a wide range of health benefits based upon his observation in humans and animals. The juice of wheatgrass is known as "green blood," which enhances the formation of RBCs in the human body and healthily stimulates tissue cell growth. Wheatgrass is considered an integral part of Indian culture since ancient times. In general, wheatgrass is known as the young grass of the common wheat plant. The other varieties of wheatgrass are Agropyron trachycaulam (slender wheatgrass), Elytrigia, Eremopyrum, Pascopyrum, and Pseudoroegneria commonly found in temperate regions of the United States and Europe a rich source of ant. Wheatgrass is ioxidants, vitamins, minerals, enzymes, and amino acids [3]. Clinically, wheatgrass juice is mainly utilized because of its antioxidant property. It is a significant herbal plant used from ancient times to treat various diseases and disorders such as high blood pressure, obesity, cancer, diabetes, gastritis, ulcers, pancreas, fatigue, anemia, asthma, hemorrhoids, halitosis, skin problem, and constipation [4]. The wheatgrass plant is also mentioned in Ayurveda as herbal medicine to treat several diseases. Furthermore, it acts as an immunomodulatory, antioxidant, laxative, astringent, diuretic, and antibacterial agent. It is also used to cure acidity, colitis, kidney malfunctioning, and swelling wounds in Ayurveda medicinal system. Besides this, the wheatgrass plant also carries pharmacological properties such as anti-inflammatory, antioxidant, anticancer, immune-modulatory, diuretic, antibacterial, anti-aging, anti-diabetic, and wound healing [5]. Tables 1 and 2 represent the vernacular names and taxonomical classification of wheatgrass plant [6].

\section{Health benefits of wheatgrass and its components}

Wheatgrass is consumed for its nutritional and therapeutic properties. It is utilized as fresh juice, a dried juice concentrate, an extract, tablet form, or as a whole leaf powder. It is nourishing and restorative in nature. The presence of chlorophyll, flavonoids, vitamins, enzymes, minerals, indole, choline, and number of amino acids are responsible for the health benefits of wheatgrass plant. The three main properties of this plant include blood purification, colon cleansing, and liver detoxification. Chlorophyll content present in wheatgrass plant refers as "green blood" or "living blood" which is considered as a primary nutrient in fresh wheatgrass. It helps in preventing cancer, hinders side effects after cancer treatment. Drinking wheatgrass juice can boost body metabolism and helps in weight loss. Wheatgrass enhances the immune system and helps in lowering blood pressure also. The wheat sprout roots extracts and leaves were known for inhibiting metabolic action of carcinogens, where chlorophyll was detected as a prime substance. Chlorophyll derivative named as Chlorophyllin showed protection of mitochondria against oxidative damage [7]. Due to the structural similarity between chlorophyll and hemoglobin which is only differ by iron and magnesium composition showed noticeable hematological benefits of chlorophyll-rich substances. The ascorbic acid, another constituent of wheatgrass showed antioxidant and pro-oxidant properties and helps in stimulation of immune system, alteration of carcinogen metabolism, enhancement of collagen synthesis, and interference with cancer cell signaling [8]. The flavonoid constituent named apigenin has been reported to show antioxidant and anti-inflammatory actions by inhibiting cytokine-induced leucocyte adhesion and also showed protective effects against cardiovascular diseases by producing EDHF (endothelial-derived hyperpolarizing factor)-mediated vascular dilation $[9,10]$. From a reported study, it was found that wheatgrass juice maintains sugar balance, improves digestion, maintains healthy hair, and helps in eliminating toxic substances out of the body. Apart from this, it is also useful in the treatment of chronic diseases like arthritis. 


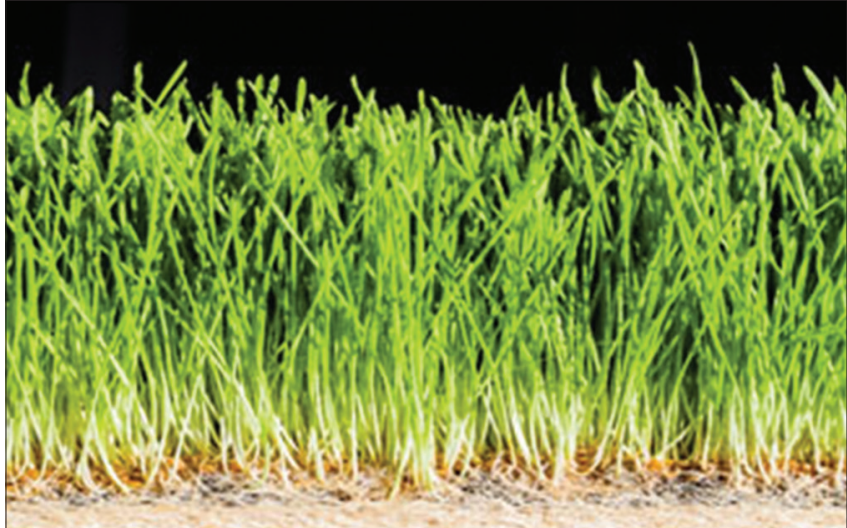

Fig. 1: Wheatgrass (Triticum aestivum Linn.)

\section{Botanical description of T. aestivum}

It is a perennial, tufted grass plant that belongs to the family Poaceae. The shoot or young grass of T. aestivum is known as wheatgrass [11]. The plant reaches up to the height of $30-100 \mathrm{~cm}$ (12 to 40 inches). The leaves of the plant are flat or somewhat rolled, spikes long, slender, somewhat flattened, dorsally compressed rachis tough, spikelet 2-5 flowered, far apart from the stem, hexaploid [12,13]. In early growth stages, the stem of the T. aestivum plant is much-compressed, glabrous, hollow except at nodes or crown bearing leaves that are alternate, simple and entire, $1.2 \mathrm{~m}$ tall, auricled, wraps around the stem, linear-lanceolate or narrow linear with length $20-38 \mathrm{~cm}$, and breadth up to $1.3 \mathrm{~cm} \mathrm{[14].}$

\section{Geographical distribution of T. aestivum}

The wheat plant was originated from the Levant region of the Near East [15]. T. aestivum plant is mainly cultivated in temperate, irrigated to dry, high rainfall areas, warm, humid to dry, and cold regions. It is native to southwest Asia and the Mediterranean region and is grown almost all over the world [16]. A total of 15-20 species of T. aestivum documented worldwide widely out of which 8 species of wheatgrass are reportedly found in India [17].

\section{PHYTOCHEMICAL CONSTITUENTS OF WHEATGRASS}

Wheatgrass is also known as "green blood." This is because of the presence of high chlorophyll content that is present in $70 \%$ of the total of its chemical constituents $[18,19]$. The juice of wheatgrass is a rich source of Vitamin A, Vitamin C, Vitamin E, and Vitamin B complex and minerals present are phosphorus, calcium, magnesium, selenium, alkaline earth metals, boron, zinc, potassium, and molybdenum. The enzymes present are amylase, protease, cytochrome oxidase, transhydrogenase, and superoxide dismutase. Wheatgrass is also a rich source of amino acids such as glutamic acid, arginine, alanine, aspartic acid, and serine [20].

Clinically, wheatgrass juice is used due to its antioxidant property because of the presence greater amount of bioflavonoids such as luteolin, quercetin apigenin, and indole components such as laetrile (amygdalin) and choline [21]. Furthermore, wheatgrass contains abscisic acid alkaloids, carbohydrates, saponins, gums and mucilage, proline, glycine, and histidine. The concentration of ferulic acid, vanillic acid, beta-carotene (pro-Vitamin A), Vitamin C, and Vitamin E rises with the growth of wheatgrass [22]. The chemical structure of some major phytochemicals is shown in Fig. 2.

\section{THE TRADITIONAL AND MODERN VIEW}

\section{Wheatgrass in Ayurveda}

The use of wheatgrass (T. aestivum Linn.) plant is mentioned in Ayurveda medicinal system. In Ayurveda, wheatgrass is used to treat acidity, colitis, kidney malfunction, swelling wounds, and vitiated conditions of Kapha and Pitta. Wheatgrass also acts as an immunomodulator,
Table 1: Vernacular names of wheatgrass (Triticum aestivum Linn.)

\begin{tabular}{ll}
\hline Language & Vernacular name \\
\hline Hindi name & Gehun, kanak \\
English & Wheatgrass \\
Sanskrit & Godhuma \\
\hline
\end{tabular}

Table 2: Taxonomical classification of wheatgrass

\begin{tabular}{ll}
\hline Taxonomical rank & Taxon \\
\hline Kingdom & Plantae \\
Division & Magnoliophyta \\
Class & Liliopsida \\
Order & Cyperales \\
Family & Gramineae/Poaceae \\
Subfamily & Pooideae \\
Tribe & Triticeae \\
Genus & Triticum \\
Species & Aestivum \\
Common name & Wheatgrass \\
\hline
\end{tabular}

Table 3: Rasapanchaka (properties) of wheatgrass (Triticum aestivum Linn.)

\begin{tabular}{ll}
\hline Sanskrit & Sanskrit / English \\
\hline Rasa & Madhur/Sweet \\
Virya & Sheet/Cold \\
Guna & Snigdha/Oily, Guru/Heavy \\
\hline
\end{tabular}

antioxidant, astringent, laxative, diuretic, and antibacterial agent. Wheatgrass also carries the property of optimizing blood sugar levels. In the present day, the wheatgrass plant is used as an antidiabetic agent yet it is not scientifically proven [17]. The ayurvedic properties of wheatgrass plant are shown in Table 2. The rasapanchak (properties) of the plant are shown in Table 3

Properties and action of wheatgrass

- Jeevniya: It boosts immunity

- Britney: It provides nourishment to the body

- Balya: It strengthens the body

- Shukrapada: It promotes reproductive health

- Pittahara: It balances Pitta dosha

- Shleshmkar: It balances Kapha dosha

- Sar: It helps in the movement of smaller nutrient particles

- Pittadahkrit: It induces the digestive fire that helps in proper digestion.

\section{Folk uses}

Wheatgrass plant is used by rural and remote areas to treat several diseases as it is a rich source of nutrients. In folk areas, it is used to cure diseases such as common cold, coughs, bronchitis, fevers, infections, and inflammation of the throat and mouth [5]. Folk practitioners used wheatgrass to treat gout, rheumatic pain, chronic skin disorder, cystitis, and constipation [23]. Many people in rural areas used wheatgrass juice as a dietary supplement as it carries anticancer properties [24]. It is used to increase hemoglobin production, preventing tooth decay, bacterial infection, and improve wound healing. It is also helpful in removing heavy metals, drug deposits, and cancer-causing agents as it removes toxins from blood and liver [25]. People also believe that wheatgrass diet boosts the immune system, kills harmful bacteria in the digestive system, and removes toxins and waste matter out of the body [26].

\section{Modern view}

The adulteration in standard medicines is a rising issue in the herbal drug industry. It affects the business exertion of traditional herbal medicines [27]. The herbal products believe in a holistic approach 


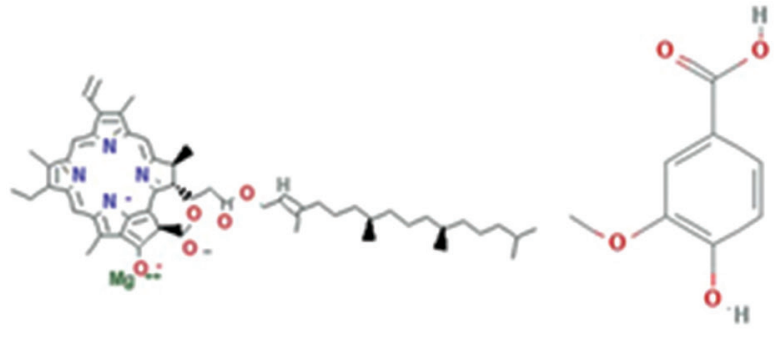

a)Chlorophyll
b)Vanillic acid<smiles>O=c1cc(-c2ccc(O)cc2)oc2cc(O)cc(O)c12</smiles>

DApigenin<smiles>NC(C(=O)O)C(O)C(=O)O</smiles>

c)Asparatic acid<smiles>N=C(N)C(=O)NCCC[C@H](N)C(=O)O</smiles>

g)Arginene<smiles>N#C[C@H](O[C@@H]1O[C@H](C(=O)O)[C@@H](O)[C@H](O)[C@H]1O)c1ccccc1</smiles>

d)Laetrile

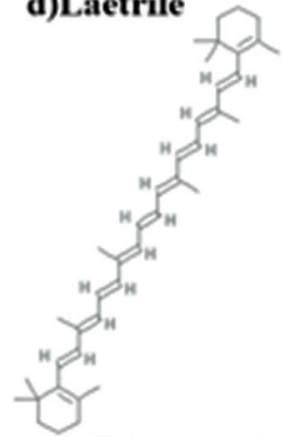

h)Beta- carotene<smiles>COc1cc(C=CC(=O)O)ccc1O</smiles>

i) Ferulic acid<smiles></smiles>

j) serine<smiles></smiles>

k)Quercetin

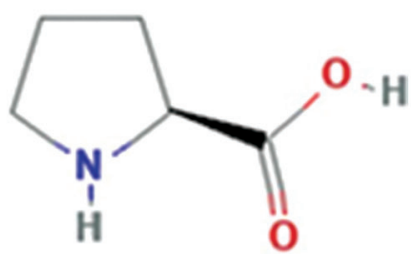

l) Proline

Fig. 2: Chemical structures of some major phytochemicals of wheatgrass plant

where allopathic medicines work only upon suppressing the disease symptoms by using various chemically modified drugs [28]. Due to overexploitation, deforestation, and loss of habitat, herbal industries are facing the unavailability of genuine plant, as a result of which adulteration rises. Adulteration in natural products results in the poor quality of the product which can cause serious health problems like severe allergies $[29,30]$. Hence, it is necessary to develop an Herbal Authentication System which can serve as a regulator and also helps in improving the quality of herbal trade [31,32].

\section{REPORTED PHARMACOLOGICAL USES OF WHEATGRASS (T. AESTIVUM LINN.)}

From various experimental and clinical studies, it was found that wheatgrass plant has numerous medicinal properties which are used to treat several ailments and disorders. Some of the reported pharmacological studies of wheatgrass plant are described below.

\section{Anticancer activity}

Selenium and laetrile present in wheatgrass possess anticancer properties. The aqueous and ethanol extracts of wheatgrass are responsible for inhibiting the growth of leukemia cells in a time-dependent manner. It was found that the aqueous extract of the wheatgrass plant shows an antiproliferative effect. The ethanolic extract of the plant shows the highest anti-proliferative property. In another in vitro study, it was found that wheat sprout extract restricts the metabolic activation of carcinogens and reducing cancer-causing ability up to $99 \%$ [33].

\section{Anti-thalassemia activity}

Chlorophyll molecule of wheatgrass has a similar structure to that of the hemoglobin molecule in humans. The only difference lies in the central element; hemoglobin has iron, whereas chlorophyll has magnesium. It has been reported that the intake of chlorophyll derivatives increases the RBCs and hemoglobin concentration up to $70-83 \%$ within 16 days. The study was conducted in thalassemia patients where $100 \mathrm{ml}$ wheatgrass juice was given to 38 patients of thalassemia major for 6 months. It showed effective results in 50\% of the patients [34]. Another study was conducted in children aged 1-3 years, 4-8 years where wheatgrass tablets were divided as $2-3$, tablets/day and given, respectively, in 40 patients of thalassemia major patients showed an increased level of hemoglobin and increase the period between blood transfusion and decrease the quantity of blood transfused [35].

\section{Antiulcer activity}

From various reported studies, it was found that wheatgrass juice showed effective results in the treatment of active distal ulcerative colitis. The study was conducted in rats where water-soluble proteins and water-soluble organic compounds showed good results in anti- 
stomach ulcer activity. Another study was conducted in guinea pigs where chlorophyll is experimented against cutaneous wounds and helps in treating dermatome donor sites clinical burns, surgical wounds, and ulcers in human patients. It was found that the aqueous solution and chlorophyll ointment is useful in the treatment of skin ulcers [36,37].

\section{Antioxidant activity}

Chlorophyll content present in wheatgrass inhibits the metabolic activation of carcinogens and oxidative DNA damage. A crude ethanolic extract showed the highest total phenolic content DPPH radicalscavenging activity, ferric reducing antioxidant power, and anti-radical activity when studied on MCF-7 breast cancer cell lines [38]. It was also found that polyphenols, flavonoids, and water extracts showed antioxidant property [39].

\section{Anti-inflammatory activity}

Chlorophyll constituent present in wheatgrass possesses antiinflammatory property and helps in the treatment of wound healing, stimulates the production of hemoglobin and RBCs in anemic animals. It is also used to treat diseases such as skin lesions, skin burns, stimulates granulation, and epithelization [37].

\section{Anti-diabetic activity}

Wheatgrass is a rich source of fibers which helps in maintaining blood sugar level. A study was conducted in diabetic rats showed that wheatgrass juice possesses hypoglycemic activity [14]. Also, the chlorophyll constituent present in wheatgrass acts as an antidiabetic agent [40].

\section{Cardioprotective and hepatoprotective activity}

The study was conducted in $\mathrm{CCL}_{4}$ treated rats to determine the hepatoprotective activity of wheatgrass given in $80 \mathrm{mg} / 100 \mathrm{~g}$ by weight in drinking water for 4 weeks. Results showed an increase in antioxidants and a decrease in oxidative stress [41]. The chlorophyll content present in wheatgrass reduces blood pressure, increases the rate of heart functioning, and the potassium present in wheatgrass helps in maintaining normal blood pressure [4]. It is also helpful in reducing total cholesterol, triglyceride level and increases good cholesterol and vitamin level when experimented within induced hypercholesterolemia rats [11].

\section{Antibacterial activity}

The wheatgrass juice (green blood) showed antibacterial activity when tested in E. coli and Staphylococcus aureus. The phytochemical screening showed the presence of various secondary metabolites in wheatgrass that shows effective results in the human body [42].

\section{Detoxifying activity}

The chemical constituent present in wheatgrass plant was tested against liver to detect its detoxifying activity. It was observed that choline inhibits the deposition of fats in the experimental animal liver when administered with rich diet in cholesterol [43]. It was also found that the indole component enhances the activity of phase I and phase II xenobiotic metabolic enzymes in the liver and intestinal mucosa [44].

\section{Anti-arthritic activity}

From the reported studies, it was found that the uncooked vegetarian diet is rich in lactobacilli hence decrease the symptoms of rheumatoid arthritis. Various other studies showed effective results of wheatgrass against rheumatoid arthritis disease $[45,46]$.

\section{Immunological activity}

Wheatgrass extract was experimented against mice model to identify its immunological activity. It was found that frozen wheatgrass extract (FWGE) increases the blastic transformation of peripheral blood T lymphocytes caused by concanavalin A [47]. FWGE was administered in mice with induced systemic lupus erythematous results in decreased autoantibody production and inhibit Th2 response [48].

\section{Skin diseases}

Scientific studies showed that the chlorophyll component present in wheatgrass inhibits the growth and development of harmful bacteria. Wheatgrass therapy showed effective results against ulcerated wounds and skin diseases by inhibiting bacterial action and promote cell activity and regeneration of skin [17].

\section{CONCLUSION}

Wheatgrass is commonly known as the youngest shoot or young grass of the common wheat plant. It is also known by the name of "green blood" because it has a nearly similar structure to that of the hemoglobin molecule. This plant has greater importance in Ayurveda medicinal system and is used to treat various ailments and disorders. It is used as a hemoglobin substitute in humans to treat thalassemia and anemic patients, which increases RBCs and blood count. Due to the presence of high chlorophyll content, it is used to improve heart and lung function. Furthermore, it carries pharmacological properties such as anticancer, anti-arthritic, antibacterial, antimicrobial, antidiabetic, antioxidant, and anti-thalassemia properties. It is the richest source of vitamins, minerals, enzymes, amino acids, and antioxidants which helps in treating diseases such as cancer, ulcer, skin diseases, and many more. From reported studies, it is clear that the wheatgrass plant contains a vast range of nutrients and other important chemical constituents and need to explore more in the areas of research and studies to develop its more therapeutic and pharmacological properties to promote its more medicinal value in the field of Ayurveda and medical sciences.

\section{AUTHORS' CONTRIBUTIONS}

We declare that this work was done by the authors named in this article and all liabilities pertaining to claims relating to the content of this article will be borne by the authors.

Dr. Gitika Chaudhary drafted the article and contributed in writing ayurvedic view of the article. Dr. Hemlata Kaurav contributed in drafting and writing pharmacological portion of plant. Shailja Choudhary contributed in data collection and writing the paper.

\section{CONFLICTS OF INTEREST}

No potential conflicts of interest were reported by the authors.

\section{AUTHORS' FUNDING}

No any funding for this article writing.

\section{REFERENCES}

1. Sen S, Chakraborty R. Revival, modernization and integration of Indian traditional herbal medicine in clinical practice: Importance, challenges and future. J Tradit Complement Med 2017;7:234-44.

2. Hänninen $\mathrm{O}$, Rauma AL, Kaartinen K, Nenonen M. Vegan diet in physiological health promotion. Acta Physiol Hung 1999;86:171-80.

3. Aydos OS, Avci A, Özkan T, Karadağ A, Gürleyik E, Altinok B, et al. Antiproliferative, apoptotic and antioxidant activities of wheatgrass (Triticum aestivum L.) extract on CML (K562) cell line. Turk J Med Sci 2011;41657-63.

4. Wigmore A. The Wheatgrass Book. Wayne, NJ Avery Publishing Group; 1985.

5. Roshan K, Rathore KS, Bharkatiya M, Goel PK, Naruka PS, Saurabh SS. Therapeutic potential of Triticum aestivum Linn. (Wheat grass or green blood therapy) in the treatment and prevention of chronic and acute diseases: An overview. Pharm Tutor 2016;4:19-27.

6. Lai CN. Chlorophyll: The active factor in wheat sprout extract inhibiting the metabolic activation of carcinogens in vitro. Nutr Cancer 1979;1:19-21.

7. Kamat JP, Boloor KK, Devasagayam TP. Chlorophyllin as an effective antioxidant against membrane damage in vitro and ex vivo. Biochim Biophys Acta 2000;1487:113-27.

8. Ullah MF, Bhat SH, Hussain E, Abu-Duhier F, Ahmad A, Hadi SM. Ascorbic acid in cancer chemoprevention: Translational perspectives and efficacy. Curr Drug Targets 2012;13:1757-71.

9. Tong X, Pelling JC. Targeting the PI3K/Akt/mTOR axis by apigenin for 
cancer prevention. Anticancer Agents Med Chem 2013;13:971-8.

10. Liao Y, Shen W, Kong G, Lv H, Tao W, Bo P. Apigenin induces the apoptosis and regulates MAPK signaling pathways in mouse macrophage ANA-1 cells. PLoS One 2014;9:2007.

11. Sharma S, Shrivastav VK, Shrivastav A, Shrivastav BR. Therapeutic potential of wheat grass (Triticum aestivum L.) for the treatment of chronic diseases. South Asian J Exp Biol 2013;3:308-13.

12. Kumar R, Dahiya R, Vaquil RD, Sharma V, Ahlawat SS. Development of healthy milk drink with incorporation of wheat grass juice. Pharm Innov J 2017;6:27-9.

13. Rana S, Kamboj JK, Gandhi V. Living life the natural way wheatgrass and health. Funct Foods Health Dis 2011:1:444-56.

14. Ashok SA. Phytochemical and pharmacological screening of wheatgrass juice (Triticum aestivum L.). Int J Pharm Sci Rev Res 2011;9:159-64.

15. Singh N, Verma P, Pandey BR. Therapeutic potential of organic Triticum aestivum Linn. (Wheat Grass) in prevention and treatment of chronic diseases: An overview. Int J Pharm Sci Drug Res 2012;4:10-4.

16. Lev-Yadun S, Gopher A, Abbo S. The cradle of agriculture. Science 2000;288:1602-3.

17. Chauhan M. A pilot study on wheat grass juice for its phytochemical, nutritional and therapeutic potential on chronic diseases. Int J Chem Stud 2014;2:27-34.

18. Fahey JW, Stephenson KK, Dinkova-Kostova AT, Egner PA, Kensler TW, Talalay P. Chlorophyll, chlorophyllin and related tetrapyrroles are significant inducers of mammalian phase 2 cytoprotective genes. Carcinogenesis 2005;26:1247-55

19. Padalia S, Drabu S, Raheja I, Gupta A, Dhamija M. Multitude potential of wheatgrass juice (green blood): An overview. Chron Young Sci 2010;1:23-8.

20. Kothari S, Jain AK, Mehta SC, Tonpay SD. Effect of fresh Triticum aestivum grass juice on lipid profile of normal rats. Indian J Pharmacol 2008;40:235

21. Bar-Sella P. Rejuvenation Health According to Dr. Ann Wigmore's Teachings. Teachings, Kiryat Ono, Israel: Shachar Ltd 1998. p. 142-52.

22. Tirgar PR, Shah KV, Thumber BL, Desai TR. Investigation into therapeutic role of Triticum aestivum (wheat) grass in busulfan induce thrombocytopenia. Int J Univ Pharm Life Sci 2011;1:91-7.

23. Byers T, Nestle M, McTiernan A, Doyle C, Currie-Williams A, Gansler T, et al. American cancer society guidelines on nutrition and physical activity for cancer prevention: Reducing the risk of cancer with healthy food choices and physical activity. CA Cancer J Clin 2002;52:92-119.

24. Gruenwald J, Brendler T, Jaenicke C. PDR for Herbal Medicines. Canary Wharf, London: Thomson, Reuters; 2007.

25. Blumenthal M. The complete German commission E monographs. In: Therapeutic Guide to Herbal Medicines. Austin, Texas: American Botanical Council; 1999.

26. Zendehbad SH, Mehran MJ, Malla SU. Flavonoids and phenolic content in wheat grass plant (Triticum aestivum). Asian J Pharm Clin Res 2014;7:184-7.

27. Ben-Arye E, Goldin E, Wengrower D, Stamper A, Kohn R, Berry E. Wheat grass juice in the treatment of active distal ulcerative colitis: A randomized double-blind placebo-controlled trial. Scand J Gastroenterol 2002;37:444-9.

28. Kokate CK, Purohit AP, Gokhale SB. Pharmacognosy. Pune, India: Nirali Prakashan; 2005.

29. Ansari SH, Islam F, Sameem M. Influence of nanotechnology on herbal drugs: A review. J Adv Pharm Technol Res 2012;3:142-6.

30. Seethapathy GS, Ganesh D, Kumar JU, Senthilkumar U, Newmaster SG, Ragupathy $\mathrm{S}$, et al. Assessing product adulteration in natural health products for laxative yielding plants, Cassia, Senna, and Chamaecrista, in Southern India using DNA barcoding. Int J Legal Med 2015;129:693-700.

31. Urumarudappa SK, Gogna N, Newmaster SG, Venkatarangaiah K, Subramanyam R, Saroja SG, et al. DNA barcoding and NMR spectroscopy-based assessment of species adulteration in the raw herbal trade of Saraca asoca (Roxb.) Willd, an important medicinal plant. Int J Legal Med 2016;130:1457-70

32. Kumar JS, Krishna V, Seethapathy GS, Ganesan R, Ravikanth G, Shaanker RU. Assessment of adulteration in raw herbal trade of important medicinal plants of India using DNA barcoding. 3 Biotech 2018;8:135

33. Chiu LC, Kong CK, Ooi VE. The chlorophyllin-induced cell cycle arrest and apoptosis in human breast cancer MCF-7 cells is associated with ERK deactivation and Cyclin D1 depletion. Int J Mol Med 2005;16:735-40.

34. Marwaha RK, Bansal D, Kaur S, Trehan A. Wheat grass juice reduces transfusion requirement in patients with thalassemia major: A pilot study. Indian Pediatr 2004:41:716-20.

35. Singh K, Pannu MS, Singh P, Singh J. Effect of wheat grass tablets on the frequency of blood transfusions in thalassemia major. Indian $\mathrm{J}$ Pediatr 2010;77:90-1.

36. Lam CR, Brush BE. Chlorophyll and wound healing: Experimental and clinical study. Am J Surg 1950;80:204-10.

37. Gahan E, Kline PR, Finkle TH. Chlorophyll in the treatment of ulcers. Arch Dermatol Syphilol 1943;47:849-51

38. Tandon S, Arora A, Singh S, Monga J, Arora S. Antioxidant profiling of Triticum aestivum (wheatgrass) and its antiproliferative activity in MCF-7 breast cancer cell line. J Pharm Res 2011;4:4601-4.

39. Kulkarni SD, Acharya R, Nair AG, Rajurkar NS, Reddy AV. Determination of elemental concentration profiles in tender wheatgrass (Triticum aestivum L.) using instrumental neutron activation analysis. Food Chem 2006;95:699-707.

40. Shaikh M, Quazi M, Nandedkar R. Hypoglycemic effect of wheatgrass juice in alloxan induced diabetic rats. Pharm Tutor 2011;1:39-40.

41. Kamboj JK, Rana SV, Ola RP, Dhawan DK, Vahiphei K. Wheatgrass and antioxidant levels in carbon tetrachloride-induced hepatotoxicity in rats. J Clin Exp Hepatol 2011;1:43.

42. Sethi J, Yadav M, Dahiya K, Sood S, Singh V, Bhattacharya SB. Antioxidant effect of Triticum aestivium (wheat grass) in high-fat dietinduced oxidative stress in rabbits. Methods Find Exp Clin Pharmacol 2010;32:233-5.

43. Best CH, Ridout JH. The effects of cholesterol and choline on deposition of liver fat. J Physiol 1933;78:415.

44. Bonnesen C, Eggleston IM, Hayes JD. Dietary indoles and isothiocyanates that are generated from cruciferous vegetables can both stimulate apoptosis and confer protection against DNA damage in human colon cell lines. Cancer Res 2001;61:6120-30.

45. Nenonen M, Helve TA, Rauma AL, Hänninen OO. Uncooked, lactobacilli-rich, vegan food and rheumatoid arthritis. Br J Rheumatol 1998:37:274-81.

46. Kumar P, Yadava RK, Gollen B, Kumar S, Verma RK, Yadav S. Nutritional contents and medicinal properties of wheat: A review. Life Sci Med Res 2011;22:1-10.

47. Hidvégi M, Rásó E, Farkas RT, Lapis K, Szende B. Effect of MSC on the immune response of mice. Immunopharmacology 1999;41:183-6.

48. Ehrenfeld M, Blank M, Shoenfeld Y, Hidvegi M. Avemar (a new benzoquinone-containing natural product) administration interferes with the Th2 response in experimental SLE and promotes amelioration of the disease. Lupus 2001;10:622-7. 